\title{
Identity and prevalence of wheat damping-off fungal pathogens in different fields of Basrah and Maysan provinces
}

\author{
Mohammed Hamza Abass* (D, Qusai Hattab Madhi and Abdulnabi Abdul Ameer Matrood
}

\begin{abstract}
Background: Wheat is the most consumed cereal crops in the world infected by several pathogens and pests causing significant losses. The most threatening pathogens are fungi which cause serious diseases on roots, leaves and heads as one of the most threatening pathogens in specific wheat-growing countries. This study aimed to identify and evaluate the prevalence of damping-off fungal pathogens in different wheat fields at Basra and Maysan provinces.

Results: Disease incidence determination and fungal isolation were carried out from two sites at Basra province (Al-Qurna and Al-Madinah) and three sites at Maysan province (Al-Amarah, Kumit, Ali Al Sharqi and Ali Al Gharbi). Al-Qurna fields had the highest disease incidence (32\%), while Ali-Alsharqi fields had the lowest one (11\%). Fourteen fungal genera were identified. Rhizoctonia solani had the highest appearance (21.6) and frequency (20.20\%) percentages followed by Fusarium solani $(16.11,14.01)$ percentages and Macrophomina phaseolina $(12.2,11.1)$ percentages. Seed treatment with $R$. solani (Rs 1 isolate) showed significant decrease in germination (56.6\%) compared to F. solani and M. phaseolina treatments. Seed treatment with R. solani (Rs1 isolate) showed significant decrease in germination (56.6\%) compared to F. solani and M. phaseolina treatments.
\end{abstract}

Conclusions: These results revealed the prevalence of wheat damping-off disease in all examined fields at both Basra and Maysan province; the highest disease incidence was seen in Basra wheat fields (Al-Qurna fields); the identification of fungal pathogens showed that the most isolated fungus was R. solani followed by F. solani and M. phaseolina. Laboratory experiments showed the pathogenicity of isolated fungi which varied according to the isolate type.

Keywords: Damping-off, Fungi, Iraq, Pathogen, Rhizoctonia solani, Wheat

\section{Background}

Wheat (Triticum aestivum L.) plays a major role in the traditional healthcare system of humans and animals, where the seeds of wheat have a large amount of phytochemicals such as alkali, saponins, glycosides, terpenoids, steroids, flavonoids and tannins. The presence of these compounds in plants may be responsible for their therapeutic effect (Pathak and Shrivastav 2015). Soft wheat flour contains high levels of gluten used in soft bread and

*Correspondence: dr.mha24@yahoo.co.uk

Plant Protection Department, College of Agriculture, University of Basrah, Basrah, Iraq cakes, while hard wheat flour is used in pasta, spaghetti and other pasta products (Marconi and Carcea 2001). Wheat belongs to the Triticeae family (=Hordeae) in the Poaceae grass family (Gramineae), the common wheat (Triticum aestivum L.), also known as bread wheat, and it is the most important staple food for nearly two billion people (36\% of the world's population). Worldwide, wheat provides approximately $55 \%$ of carbohydrates and $20 \%$ of the calories consumed worldwide. It exceeds in area and production every other cereal crop (including rice, corn, etc.), and therefore, it is the most important cereal crop in the world (Minati and Ameen 2019). Wheat is the main cultivated crop and the highest grain 
used by humans in Iraq. In 2017 the wheat area harvested in Iraq was 1,047,531 ha and the production was 2,974,136 MT (FAO 2018). Wheat plants are susceptible for different disease pathogens infecting root, leaf and head causing serious diseases and greatly affect productivity all over the world. Root diseases can cause losses of 3 to $4 \%$, depending on the variety, the severity of the disease and the appropriate climate for disease development (Kaur 2016). Additionally, many studies showed that the root disease causes a loss of global yield from 10 to $15 \%$ and the fungus Rhizoctonia solani causes loss of yield of $25-100 \%$ of the global wheat production every year. In 2012, losses amounted to about 140 million tons, equivalent to 35 billion dollars (Pooja et al. 2015). Mesterhazy et al. (2005) mentioned that many fungal pathogens cause root rot by invading and colonizing the

\section{Evaluation of disease incidence}

The incidence of root rot and damping disease was estimated for the agricultural season 2019/2020 for wheat crops in some fields at Basrah province, which are AlQurna and Al-Madinah, and Maysan province, which are Amarah, Kumit, Ali Sharqi and Ali Gharbi (sampling map; Fig. 1). The incidence of root rot and damping-off was calculated based on the coloration of the primary and secondary root, noting the symptoms of dampingoff above the soil surface two months after planting. The incidence of the disease was evaluated by collecting a number of square meters of wheat plants (roots and seedlings) that were randomly captured from each field. Representative sample was performed according to the collection method based on observing symptoms of diseased plants which are randomly taken from each field (Yonghao 2013). The application of following formula:

Disease incidence percentage $=\frac{\text { Total number of symptomatic plants }}{\text { Total number of inspected plants }} \times 100$

roots of the wheat plant and entering the seedling tissue and causing damage to the crown and root tissues. Fusarium graminearum, which causes crown rot, and Bipolaris sorkiniana, the common root rot pathogen, and Gaeumannomyces graminis, the cause of take all disease, are among the main causes of wheat root diseases. These fungi can affect seed germination and cause seed blight (Tunali et al. 2008). Wheat is also infected with Fusarium spp., which causes damage to young grains, seedlings, roots, crowns and base stems, causing rotting, and in some cases, infecting the head and affecting the quality of grains and causing losses of up to $50 \%$ (Nicol et al 2004). Paulitz et al. (2002) mentioned that wheat is infected with Rhizoctonia spp., which causes cereal and crown rot, root rot and bare patch disease caused by Rhizoctonia solani Kuhn AG-8, which causes lesion, crown rot, also the fungus Pythium spp., which causes losses under moist soil conditions. And the appearance of spots and dwarfism on the plant, and the fungi grow inside the root, crown and base of the stems, and the fungus infects the germinating seeds and the top of the roots, which leads to the removal of the fine roots and root hairs and causes root rot. The present research focuses on the identification and prevalence evaluation of wheat damping-off fungal pathogens in different fields at Basrah and Maysan provinces.

\section{Methods}

The study was conducted at the laboratory of the Plant Protection Department/College of Agriculture University of Basrah. was used to calculate the incidence percentage for disease.

Isolation and identification of fungi from wheat roots:

Samples were collected from the roots that showed symptoms of rot, and the root zone was separated from the rest of plants, the infected areas then washed with running water for $30 \mathrm{~min}$ and left for a period to dry on Whatman NO. 1 filter papers. These washed parts were cut into small pieces of $0.5 \mathrm{~cm}$ in length and sterilized

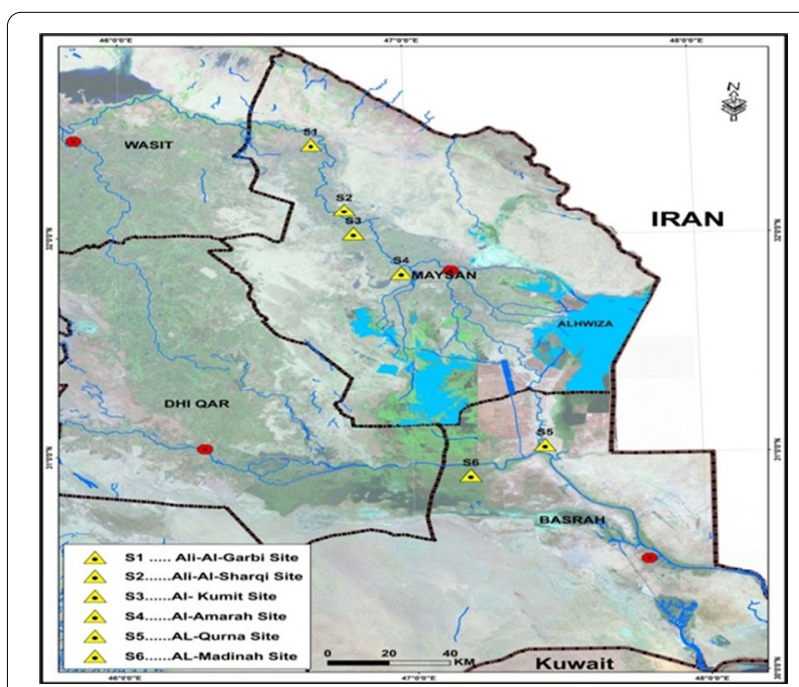

Fig. 1 Map of sites for sampling the roots of wheat and soil in Basra and Maysan province 
with a solution of sodium hypochlorite $2 \%$ of the commercial preparation for $3 \mathrm{~min}$, then washed with sterile distilled water for a minute to remove remaining sterile solution, dried on filter papers. Subsequently, four pieces were transferred to each Petri dish containing a medium of potato dextrose agar (PDA) amended with chloramphenicol at a concentration of $250 \mathrm{mg} / \mathrm{L}$. The dishes were incubated at a temperature of $25 \pm 2{ }^{\circ} \mathrm{C}$ for 3 days, and the fungi developing to the species level were diagnosed based on the classification characteristics adopted in Watanabe (2002), Dugan (2006), Leslie and Summerell (2006), Domsch et al. (2007) and Nyongesa et al. (2015). The percentage of appearance and frequency of fungal isolates were calculated according to the following equations. then incubated again at $25 \pm 2{ }^{\circ} \mathrm{C}$. After 3 days germination percentage was calculated according to the following formula:

$$
\text { Germination } \%=\frac{\text { Number of geminated seeds }}{\text { Total number of seeds }} \times 100
$$

\section{Pathogenicity experiment of fungal isolates in pots:}

The experiment was conducted in the green house of the Plant Protection Department/College of Agriculture. Pathogenicity of all examined fungal isolates was tested using sterile soil mixture using autoclave. Aseptic soil was distributed into plastic pots of $1-\mathrm{kg}$ capacity in equal quantities. Fungal inoculum was loaded with local millet seeds and added according to Dewan's method at a rate

Fungal appearance $\%=\frac{\text { Number of apperance for each fungus }}{\text { Total number of samples }} \times 100$

Fungal frequency $\%=\frac{\text { Number of fungl colonies }}{\text { Total number of all fungal colonies }} \times 100$

\section{Collection of soil samples from wheat fields}

Compound soil samples were taken at a depth of $30 \mathrm{~cm}$ from each plant sampling site. The samples were mixed from each site, and the sample size was reduced by homogeneous distribution of the soil.

\section{Isolation and identification of fungi from soil:}

After collecting the composite soil samples and brought to the laboratory, the dilution method was performed for each sample using five serial dilutions (Farazimah et al. 2019). One milliliter of the fifth dilution was added to of $2 \%(w / w)$ (Jones et al. 1984; Dewan 1989) and mixed well. The soil then moistened and the pots were covered with perforated polyethylene bags for 3 days. Sterile wheat seeds were treated superficially with sodium hypochlorite solution for three minutes. Ten seeds per pot were planted using three replicates per treatment. After the seedlings appeared, the following parameter was calculated:

$$
\text { Germination } \%=\frac{\text { Number of geminated seeds }}{\text { Total number of seeds }} \times 100
$$

$$
\text { Seedling damping - off } \%=\frac{\text { Number of damping - off seedling }}{\text { Total number of seedlings }} \times 100
$$

the surface a Petri dish containing sterile PDA medium and stirring the dish to smoothly disperse the suspension. The dishes were incubated at a temperature of $25 \pm 2{ }^{\circ} \mathrm{C}$ until the growth of the fungi appeared, and the fungi were purified and incubated at a temperature of $25 \pm 2{ }^{\circ} \mathrm{C}$ for 3-4 days. Fungal identification was applied as mentioned previously.

\section{Pathogenicity of fungal isolates}

Pathogenicity test was carried out by placing a disc $(0.5 \mathrm{~cm})$ of 7 -day-old pure culture of each fungus for three replicates on water agar plates in the center and incubated at $25 \pm 2{ }^{\circ} \mathrm{C}$ for $48 \mathrm{~h}$. Ten sterile wheat seeds were planted at $1 \mathrm{~cm}$ from the edge of each plate and
Radicle and hypocotyl length (cm): Five normal seedlings were taken from each treatment randomly, measured using a ruler (AOSA 1983).

Fresh and dry weight of radicle and hypocotyl $(\mathrm{mg})$ : The same seedlings were used to measure the length of radicle and hypocotyl. The radicle and hypocotyl were weighed separately and then placed in perforated bags in an electric oven at $80^{\circ} \mathrm{C}$ for $24 \mathrm{~h}$ for dry weight (ISTA 2005).

\section{Statistical analysis}

The experiment was designed using a complete randomization design (CRD), and the least significant difference (LSD) test was used to compare the averages at the 
0.05 probability level. The Statistical Package for Social Science (S.P.S.S.) version (23) in data analysis was used. Results represented an average of three replicates per treatment.

Table 1 Percentage of damping-off disease incidence of wheat in Basrah and Maysan province

\begin{tabular}{ll}
\hline Sites & $\begin{array}{l}\text { Disease } \\
\text { incidence } \\
\text { (D.I) \% }\end{array}$ \\
\hline Al-Qurna & 32 \\
Al-Madinah & 26 \\
Al-Amarah & 30 \\
Kumit & 19 \\
Ali-Al Sharqi & 11 \\
Ali-Al Gharbi & 15 \\
\hline
\end{tabular}

\section{Results}

Disease incidence determination and fungal isolation were carried out from two sites at Basra province (Al-Qurna and Al-Madinah) and three sites at Maysan province (Al-Amarah, Kumit, Ali Al Sharqi and Ali Al Gharbi). Al-Qurna fields had the highest disease incidence (32\%), while Ali-Alsharqi fields had the lowest one $(11 \%)$ as shown in Table 1 . Based on the obtained results, it was obvious that there were differences in the incidence of the disease among the wheat fields of the six selected sites (Fig. 2).

\section{Isolation and identification of fungi}

The results of isolation and identification showed different species of fungi isolated from wheat roots and soil of wheat fields in Basra and Maysan province, 16 species belongs to different fungi from wheat roots, and 13 genus of fungi have been isolated from the soil. The
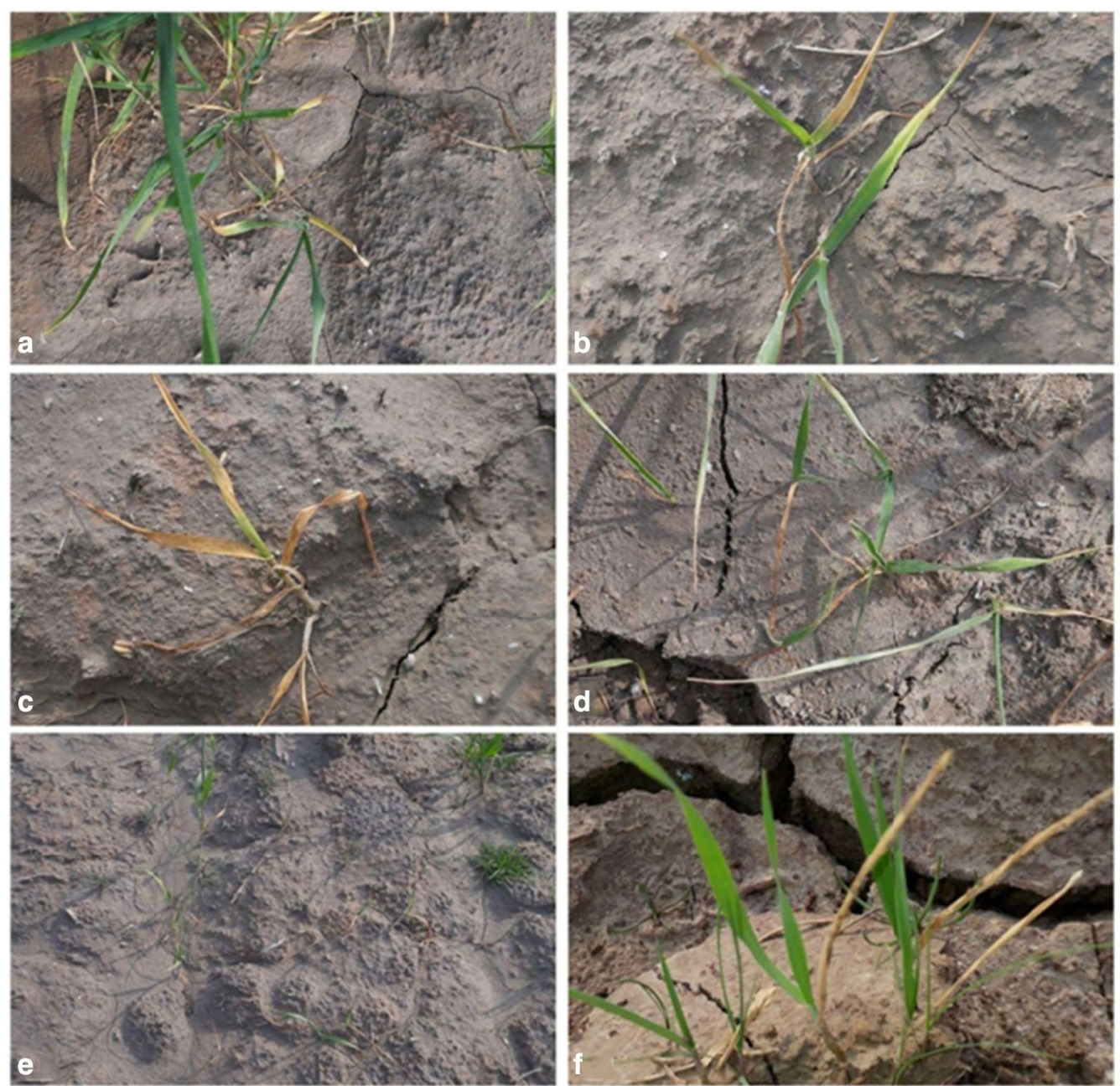

Fig. 2 Wheat damping-off symptoms on different samples from: a Al-Qurna, b Al-Madinah, c Al-Amarah, d Kumit, e Ali-Al Sharqi, f Ali-Al Gharbi fields 
fungal isolates from the Al-Qurna fields were Rhizoctonia solani (Rs1 and Rs2), Fusarium solani (Fs1), Macrophomina phaseolina (Mph1), F. oxysporum, F. roseum, F. verticillioides, F. chlamydosporum, Bipolaris sp., Alternaria alternata, Phoma sp., Aspergillus fumigatus and A. flavus from roots and R. solani (Rs3), F. solani (Fs2), F. moniliforme, $F$. avenaceum,Monilia sp., A. niger, A. fumigatus, and Mucor sp. from the soil. The fungal isolates from Al-Madinah fields were $R$. solani (Rs5), F. solani (Fs3 and Fs4), F.oxysporum, F. roseum, F. verticillioides, Cladosporium oxysporum, A. fumigatus from roots, $R$. solani (Rs6) and F. oxysporum, A. flavus, A. terreus, A. niger, Rhizopus stolonifer and Penicillium sp. from the soil, while the fields of Al-Amarah the following fungi $R$. solani (Rs8 and Rs9), M. phaseolina (Mph2), Froseum, $F$. avenaceum and A. fumigatus, A. sojae, Mucor sp., Pacilomyces sp. from the roots, $R$. solani (Rs7), F. moniliforme, R. stolonifer, A.flavus, A. terreus, A. oryzae and Penicillium sp. from the soil, whereas from the Kumait fields obtained fungi from the roots were $R$. solani (Rs10), $F$. oxysporum, A. alternata, Bipolaris sp., $R$. solani (Rs11), A. terreus, A. flavus, and Penicillium sp., and from Al-Al Sharqi fields R. solani (Rs12), F. oxysporum, and Mucor sp. from Roots, R. solani (Rs13), A.niger and R. stolonifer were from the soil, and from the Ali-Al Gharbi fields of R. solani (Rs14), F. solani (Fs5) M. phaseolina (Mph3), A. alternata, Mucor sp., Penicillium sp., A.flavus from the roots, $R$. solani (Rs15) and A. flavus A. niger, R. stolonifer, and Penicillium sp. as shown in Table 2 and Figs. 3, 4, 5, 6, 7,8 and 9.

\section{The percentage of appearance and frequency of fungi isolated from wheat roots and soil}

Table 3 shows that the highest appearance and frequency percentages of the fungus Rhizoctonia solani were 21.6 and $20.4 \%$, respectively, followed by Fusarium solani with an appearance and frequency of 16.11 and $14.01 \%$, respectively, and by Macrophomina phaseolina with an appearance and frequency of $12.5 \%$ and $11.1 \%$, respectively. As for the rates of appearance and frequency of fungi isolated from the soil, which are shown in Table 4, the fungus $A$. flavus recorded an appearance rate of $18 \%$,

followed by Rhizopus stolonifer and A. niger with an appearance rate of 16 and $11.6 \%$, respectively. The appearance of other fungi ranged from 2.3 to $10.2 \%$, and A. flavus recorded a frequency ratio of $11.9 \%$, while the frequency of other fungi ranged from 2 to $11.1 \%$.

\section{Description of fungi}

Fifteen isolates of $R$. solani fungi were isolated and identified from the roots of wheat and surrounding soil from the study fields, Fig. 4. Variation of isolates was observed in the phenotypic characteristics of the fungal culture on
Table 2 Fungal isolates from different wheat fields at Basra and Maysan province

\begin{tabular}{|c|c|c|}
\hline Sites & Roots & Soil \\
\hline \multirow[t]{12}{*}{ Al-Qurna } & Alternaria alternata & Aspergillus niger \\
\hline & Aspergillus fumigatus & A. fumigatus \\
\hline & A. flavus & F. avenaceum \\
\hline & Bipolaris sp. & Fusarium solani (Fs2) \\
\hline & Macrophomina phaseolina (Mph1) & F.moniliforme \\
\hline & Fusarium solani (Fs 1) & Mucor sp. \\
\hline & F. verticillioides & Monilia sp. \\
\hline & F.chlamydosporum & Rhizoctoni solani (Rs3) \\
\hline & F.oxysporum & \\
\hline & F.roseum & \\
\hline & Phoma sp. & \\
\hline & Rhizoctonia solani (Rs1,Rs2) & \\
\hline \multirow[t]{7}{*}{ Al-Madinah } & A. fumigatus & Aspergillus flavus \\
\hline & Cladosporium oxysporum & A. terreus \\
\hline & F.solani (Fs3) & A. niger \\
\hline & F. oxysporum & F. oxysporum \\
\hline & F.roseum & Penicillium sp. \\
\hline & F. verticillioides & Rhizopus stolonifer \\
\hline & R. solani (Rs4, Rs5) & R. solani (Rs6) \\
\hline \multirow[t]{9}{*}{ Al-Amarah } & A. fumigatus & Aspergillus flavus \\
\hline & A. sojae & A. terreus \\
\hline & F. roseum & A. oryzae \\
\hline & F. avenaceum & F. moniliforme \\
\hline & F. solani (Fs4) & Penicillium sp. \\
\hline & M. phaseolina (Mph2) & Rhizopus stolonifer \\
\hline & Mucorsp. & R. solani(Rs7) \\
\hline & Pacilomyces sp. & \\
\hline & R. solani (Rs8,Rs9) & \\
\hline \multirow[t]{4}{*}{ Kumit } & A. alternata & A. terreus \\
\hline & Bipolaris sp. & A. flavus \\
\hline & F.oxysporum & Penicillium sp. \\
\hline & F. oxysporum & R. solani (Rs 11) \\
\hline \multirow[t]{3}{*}{ Al-Al Sharqi } & R. solani (Rs10) & Rhizopus stolonifer \\
\hline & A. alternata & Aspergillus flavus \\
\hline & Mucor sp. & A. niger \\
\hline \multirow[t]{7}{*}{ Ali-Al Gharbi } & R. solani (Rs 12) & R. solani (Rs 13) \\
\hline & A. flavus & A. niger \\
\hline & F. solani (Fs5) & Penicillium sp. \\
\hline & M. phaseolina (Mph3) & Rhizopus stolonifer \\
\hline & Mucorsp. & R. solani (Rs15) \\
\hline & Penicillium sp. & \\
\hline & R. solani (Rs 14) & \\
\hline
\end{tabular}

the PDA culture medium after incubation for 3 weeks at a temperature of $25 \pm 2{ }^{\circ} \mathrm{C}$, isolates were varied between light brown and dark brown, while some isolates were distinguished by white in the early stages of growth, then turned to light brown. As well as a variation in the 


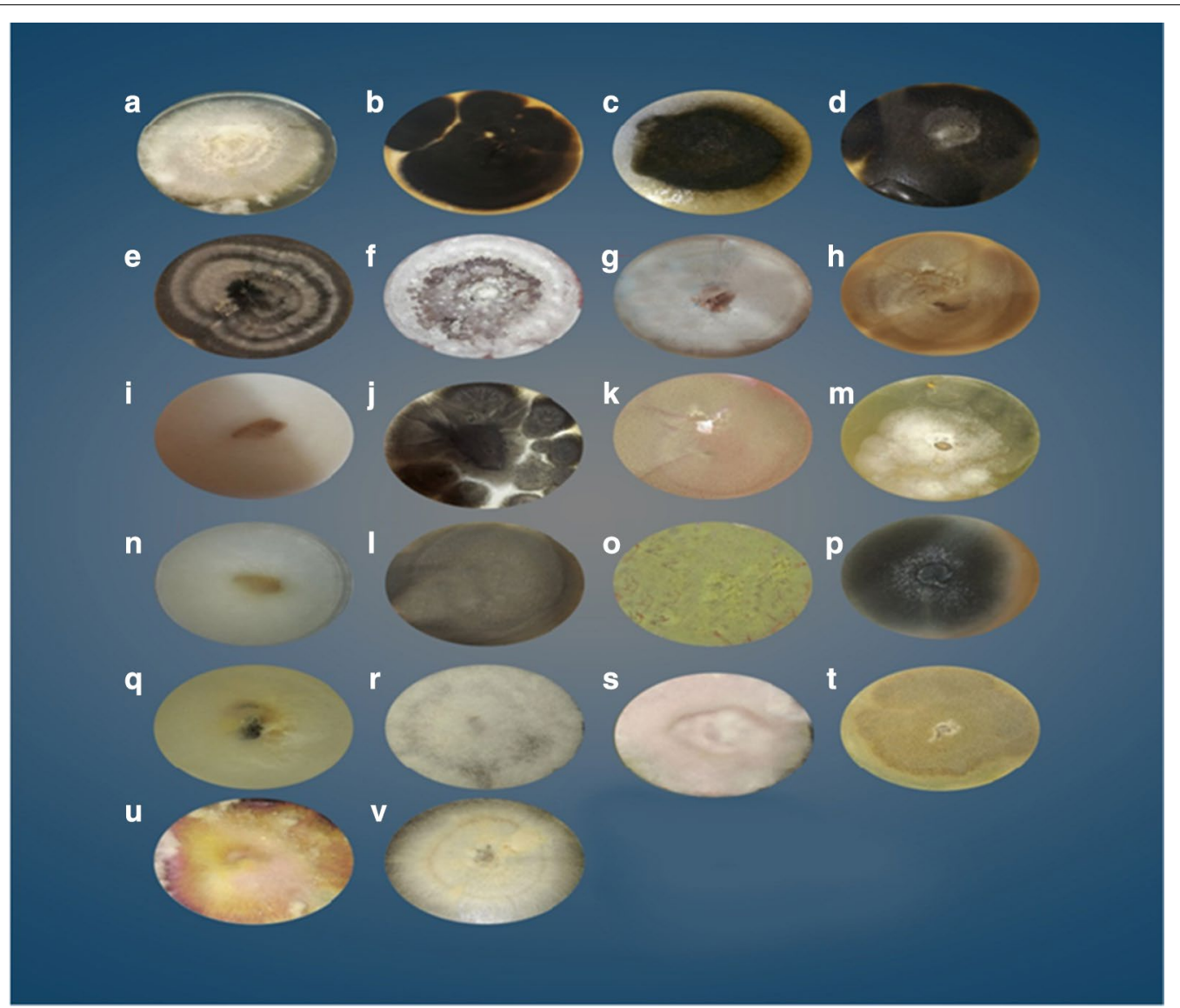

Fig. 3 Fungal isolates from roots and soils from different wheat fields: A. F. verticillioides B.C: a F. verticillioides, b C. oxysporum, c Phoma sp., d. A. alternata, e Bipolaris sp., f F. oxysporum, $\mathbf{g}$ A. flavus, $\mathbf{h}$ A. terreus, i Mucor sp., j A.niger, $\mathbf{k}$ A. fumigatus, I Monilia sp., $\mathbf{m}$ R. stolonifer, $\mathbf{n}$ A. oryzae, o A. sojae, $\mathbf{p}$ A. parasiticus, q Penicillium sp., $\mathbf{r}$ F. monilifome, $\mathbf{s}$ F. avenaceum, $\mathbf{t}$ Pacilomyces sp., $\mathbf{u}$ F. roseum, $\mathbf{v}$ F. chlamydosporum

color of the obverse of the fungal colonies, as the colors ranged from dark yellow to light yellow to light brown, different growth patterns and the density of air fungal were examined. It was also noticed that there were common characteristics among the isolates of fungi, which are branching type of the fungal spinning in a right angle and containing constriction in the areas of the origin of the branch and the formation of barriers in the branches near the area of development and without any sexual forms, and the presence of different forms of fungi spinning branches, and all the isolates were producing sclerotia with brown to dark brown color with a difference in their density, as well as the spread on the culture medium PDA, as the isolates Rs1, Rs5 and Rs9 showed their ability to form barrel-shaped bulging cells in the form of long or short chains called monilioid cells (Fig. 5).

Three isolates of $F$. solani were obtained from the study fields, Fig. 6, and the fungus was characterized by producing white to creamy hyphae on the PDA culture medium after incubation for a period of 3 weeks at a temperature of $25 \pm 2{ }^{\circ} \mathrm{C}$. The colony's texture is lumbar, and its edges are regular. All fungal isolates produced macro- and microconidia and chlamydospores, all of which are hyaline. Macroconidia were relatively broad in the form of a sickle with the blunt end with dimensions $4-5 \times 26-28 \mathrm{~nm}$, and the number of septa is $2-3$. As macroconidia were oval or nephrotic as they are $2-3 \times 8-10 \mathrm{~nm}$ and may be not divided or divided by one or two septa, chlamydospores were intercalary, terminal, globose to oval shaped in all the isolates as shown in Fig. 7.

Three isolates were obtained from the M. phaseolina fungus (Table 2, Fig. 8), isolates were identified on the PDA culture medium after three weeks of incubation at a temperature of $25 \pm 2{ }^{\circ} \mathrm{C}$ according to the microscopic examination, the mycelium is divided and branched, and it is hyaline at the beginning, then it turns green, and olive brown, finally black, with the age of the colony. The conidia are single-celled ovals, and the size ranges 


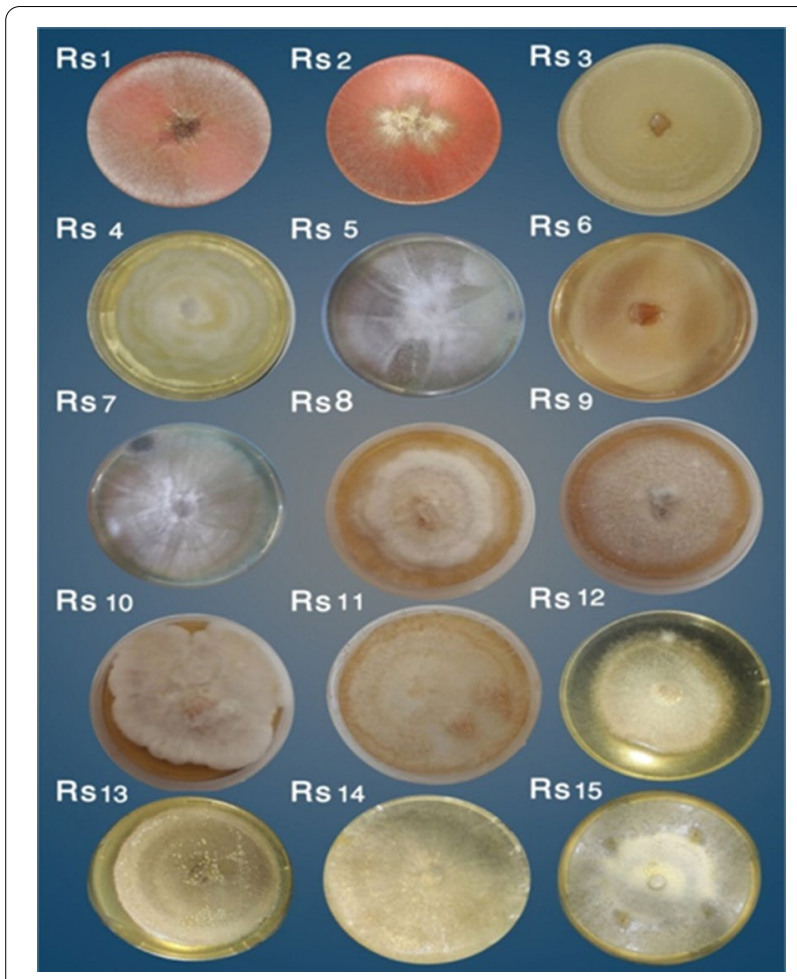

Fig. 4 Different culture of $R$. solani isolated from infected soil and wheat root samples

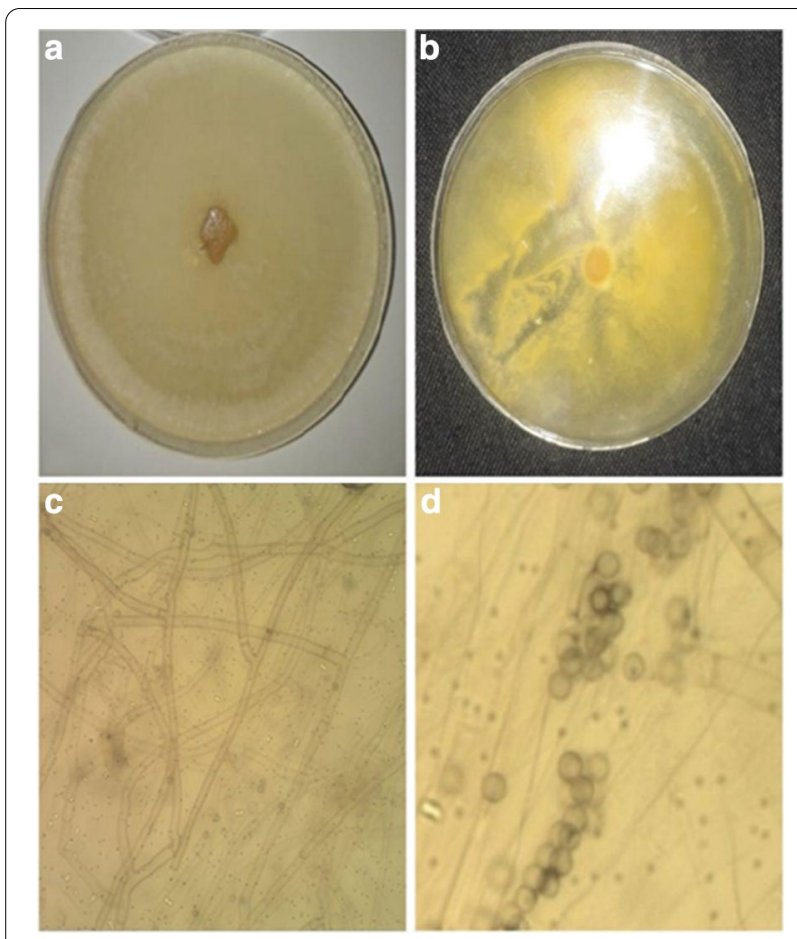

Fig. 5 a $R$. solani on PDA (top), b R. solani on PDA (bottom), chypha of $R$. solani branched at almost right angle with a narrow restriction near the branch area with a transverse barrier. $\mathbf{d}$ Monilioid cells

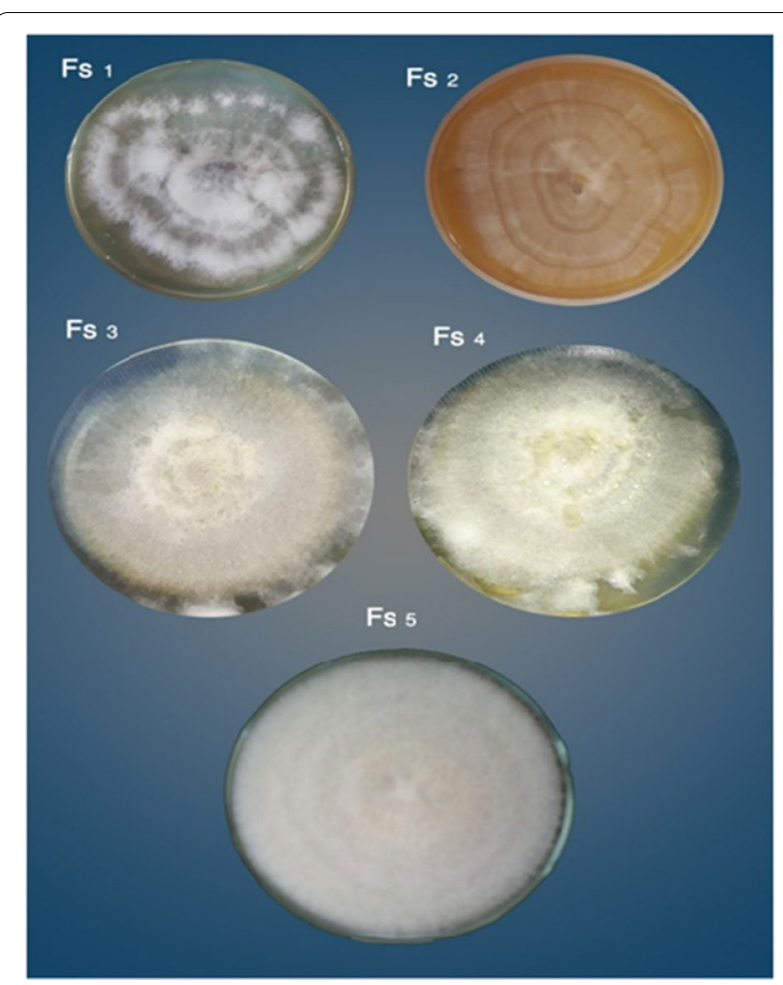

Fig. 6 Different culture of F. solani isolated from infected soil and wheat root samples
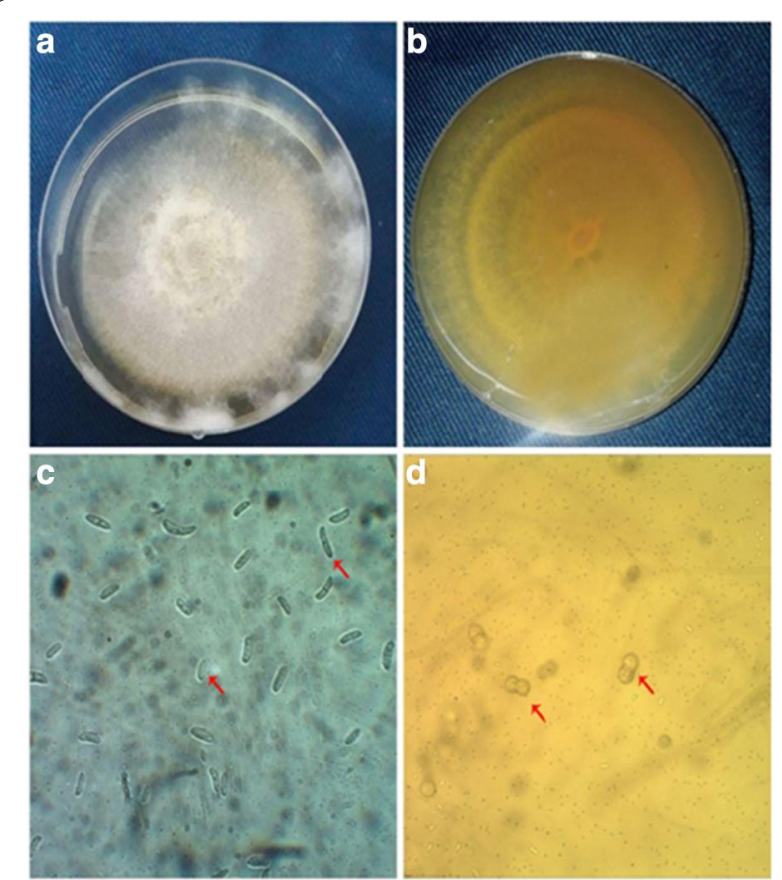

Fig. 7 a F. solani on PDA (TOP), b F. solani on PDA (bottom), c macroconidia and macroconidia, $\mathbf{d}$ chlamydospore 


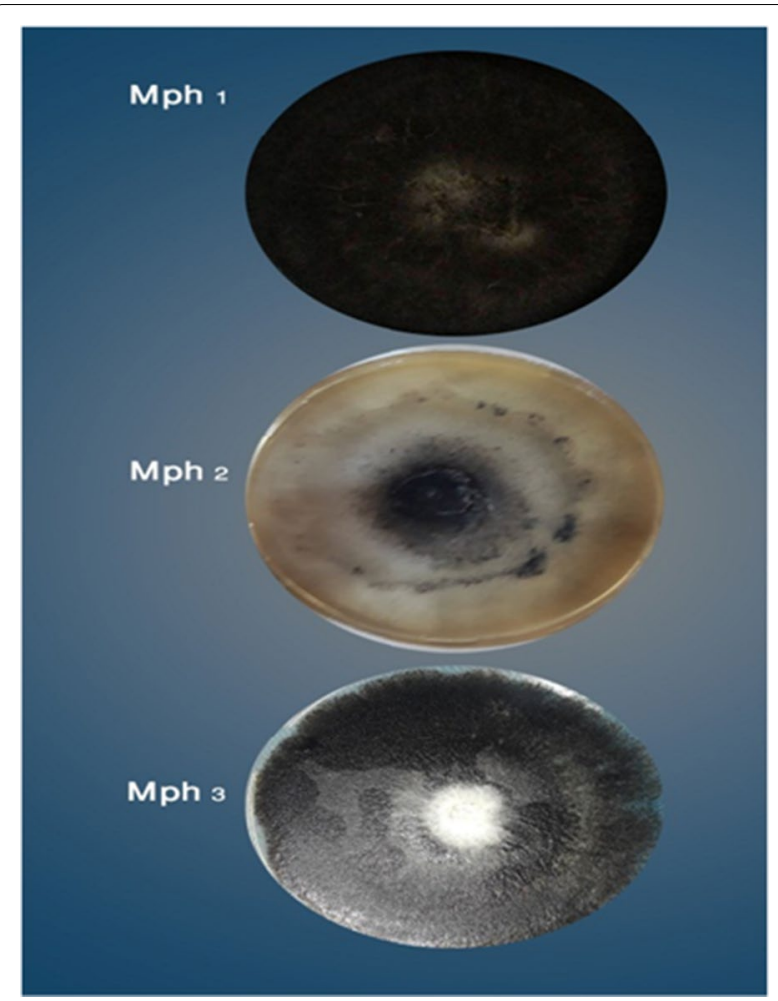

Fig. 8 Different culture of M. phaseolina isolated from infected soil and wheat root samples

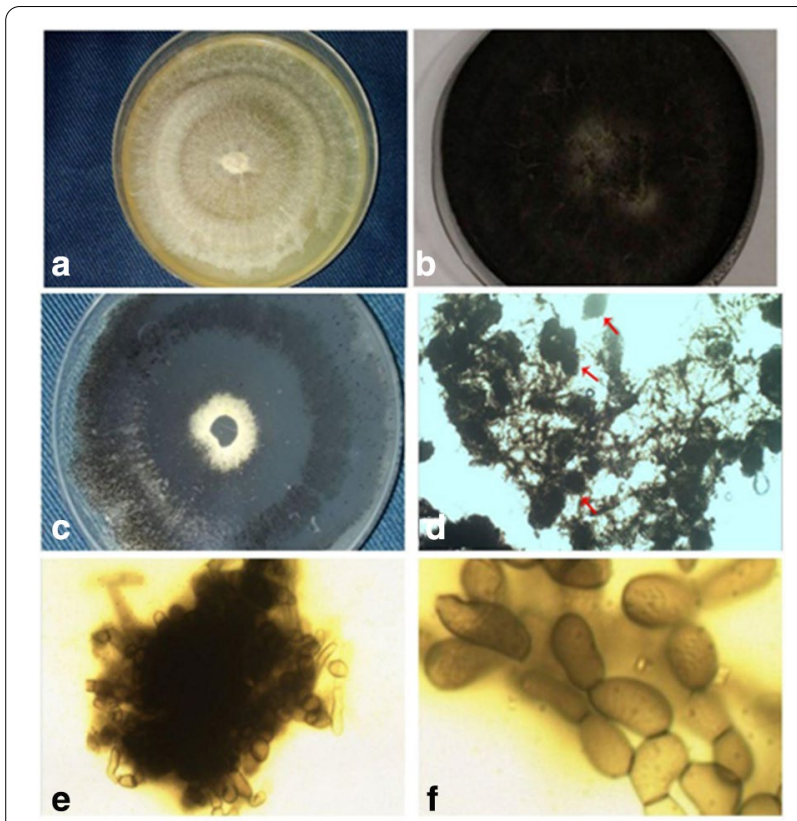

Fig. 9 a M. phaseolina on PDA are one week (top), b M. phaseolina on PDA are three week (top), $\mathbf{c}$ M. phaseolina on PDA (bottom), $\mathbf{d}$ Pycnidia, e sclerotia, $\mathbf{f}$ conidia
Table 3 Percentage of frequency and appearance of fungi isolated from roots of infected wheat plants

\begin{tabular}{llll}
\hline No & Isolates & \% appearance & \% frequency \\
\hline 1 & Rhizoctonia solani & 21.6 & 20.4 \\
2 & Fusarium solani & 16.11 & 14.01 \\
3 & Macrophomina phaseolina & 12.5 & 11.1 \\
4 & Fusarium oxysporum & 8.5 & 9.9 \\
5 & Alternaria alternata & 7.7 & 9.1 \\
6 & Fusarium verticilloides & 6.6 & 6 \\
7 & Fusarium roseum & 5.2 & 5.3 \\
8 & Fusarium chlamydosporum & 2.4 & 1.9 \\
9 & Phoma sp. & 2.2 & 3 \\
10 & Aspergillus fumigatus & 4.5 & 2.7 \\
11 & Bipolaris sp. & 3.1 & 2.6 \\
12 & Aspergillus flavus & 2.5 & 2.1 \\
13 & Apergillus sojae & 2.5 & 2 \\
14 & Penicillium sp. & 2.2 & 1.5 \\
15 & Mucor sp. & 1.29 & 1.3 \\
16 & Cladosporium oxysporum & 1.1 & 1.1 \\
\hline
\end{tabular}

Table 4 Percentage of frequency and appearance of fungi isolated from infected soil

\begin{tabular}{llll}
\hline No & Isolates & \% appearance & \% frequency \\
\hline 1 & Rhizoctonia solani & 4.4 & 2 \\
2 & Fusarium solani & 6.3 & 7.7 \\
3 & Macrophomina phaseolina & 3.7 & 1.2 \\
4 & Aspergillus niger & 11.6 & 9 \\
5 & Aspergillus terreus & 10.2 & 11.1 \\
6 & Aspergillus flavus & 18 & 11.9 \\
7 & Rhizopus stolonifer & 16 & 8.4 \\
8 & Penicillium sp. & 7.8 & 6.1 \\
9 & Aspergillus fumigatus & 9.7 & 10.6 \\
10 & Aspergillus oryzae & 5.2 & 5 \\
11 & Mucor sp. & 2.7 & 2.4 \\
12 & Fusarium oxysporum & 2.3 & 2 \\
13 & Monilia sp. & 2.1 & 1.6 \\
\hline
\end{tabular}

from 7-10 $\times 18-23 \mathrm{~nm}$. Pycnidia is spherical black with dimensions ranging from 140 to $190 \mathrm{~nm}$ (Fig. 9).

\section{Effect of R. solani, F. solani and M. phaseolina treatment} on germination of wheat seeds

The results showed a significant variation in the effect of fungal isolates on the germination of wheat seeds in Petri dishes (Table 5, Fig. 10). Rs1 isolate was the most effective, as the percentage of germination of wheat seeds was reduced to $56.6 \%$ compared to the control treatment which was $100 \%$ and with significant differences than the other isolates, followed by Fs1 and Mph1 isolates with a 
Table 5 Seed germination and damping-off percentage of wheat in plates and pots experiments

\begin{tabular}{|c|c|c|c|c|}
\hline No & Isolate & $\begin{array}{l}\text { Germination } \\
\text { percentage } \\
\% 100 \text { (dishes) }\end{array}$ & $\begin{array}{l}\text { Germination } \\
\text { percentage } \\
\% 100 \text { (pots) }\end{array}$ & $\begin{array}{l}\% \\
\text { Damping- } \\
\text { off (pots) }\end{array}$ \\
\hline 1 & Control & 100 & 100 & 0 \\
\hline 2 & Rs1 & 56.6 & 46.3 & 71.6 \\
\hline 3 & Rs2 & 80 & 73.3 & 31.4 \\
\hline 4 & Rs3 & 73.3 & 76.6 & 30 \\
\hline 5 & Rs4 & 73.3 & 63.3 & 30.9 \\
\hline 6 & Rs5 & 76.6 & 63.3 & 28.6 \\
\hline 7 & Rs6 & 70 & 63.3 & 29.5 \\
\hline 8 & Rs7 & 90 & 86.6 & 7.4 \\
\hline 9 & Rs8 & 90 & 73.3 & 25 \\
\hline 10 & Rs9 & 70.0 & 60.0 & 36.9 \\
\hline 11 & Rs10 & 70 & 63.3 & 36.4 \\
\hline 12 & Rs11 & 93.3 & 76.6 & 27.3 \\
\hline 13 & Rs12 & 86.6 & 83.3 & 17.8 \\
\hline 14 & Rs13 & 80.0 & 63.6 & 22.2 \\
\hline 15 & Rs14 & 86.6 & 73.3 & 24.9 \\
\hline 16 & Rs15 & 70 & 60.0 & 28.8 \\
\hline 17 & Fs1 & 66.6 & 56.6 & 41.6 \\
\hline 18 & Fs2 & 93.3 & 93.3 & 3.6 \\
\hline 19 & Fs3 & 83.3 & 76.6 & 25.5 \\
\hline 20 & Fs4 & 80 & 76.6 & 17.2 \\
\hline 21 & Fs5 & 80 & 83.3 & 10.3 \\
\hline 22 & Mph 1 & 63.3 & 53.3 & 47.5 \\
\hline 23 & Mph 2 & 80 & 73.3 & 31.5 \\
\hline \multirow[t]{2}{*}{24} & Mph3 & 93.3 & 86.6 & 11.6 \\
\hline & L.S.D & 12.142 & 6.819 & 26.014 \\
\hline
\end{tabular}

percentage of germination 66.6 and 63.3\%, respectively. The isolates Rs6, Rs15 and Mph1 recorded a germination percentage of $70 \%$, with significant differences from the $100 \%$ control treatment. The results also revealed a significant difference in the effect of fungal isolates on the germination of wheat seeds and the damping-off in the wheat plant in the pots, and the Rs1 isolate was more effective than the other isolates, with the percentage of seed germination and damping-off 46.3 and $71.6 \%$, respectively, followed by the Fs1 and Mph1 isolates, as the percentage of seed germination and dampingoff reached (56.6, 41.6\%) and (53.3,47.5\%), respectively (Table 5).

The results in Table 6 showed that all fungal isolates had a significant effect on reducing the radicle and hypocotyl length, as well as on the fresh and dry weight of radicle and hypocotyl, the Rs1 isolate was more effective than the other isolates, followed by Rs9, Fs1 and Mph1.

\section{Discussion}

Based on field survey, the results elucidated high severity indices of damping-off disease in wheat fields at Basra province; most of wheat seedlings showed a typical symptoms of the examined disease, and the disease severity indices were varied among the wheat fields and thus could be attributed to the different types of varieties, planting date, seeding rate, fertilizer usage and agricultural rotation, as well as to agricultural practices used by farmers at each field (Ernesto et al. 2015). Soilborne pathogens are commonly known to cause serious $t$ diseases in wheat and other crops, resulting in yield losses, stand reductions, white heads and rotting of root, crown, subcrown, as well as lower parts of stem tissues (Andrade et al. 2011). Among the important soilborne pathogens are members of the Fusarium complex, responsible for fusarium crown and root rot (FCR) of wheat (Cook 2010). Other important genera of pathogens that can affect seedlings, crowns and fodder are Bipolaris sorokiniana and Rhizoctonia spp. With high ability to cause diseases such as a common root rot and root rot of Rhizoctonia sp. (Acuña 2008), the fungal pathogens of wheat plants are able to cause several diseases in different patterns including singularly or in co-exist at the same wheat field, or even within same plants (Paulitz et al. 2002). Results of identification and prevalence of fungal pathogens showed that Rhizoctonia, Fusarium as well as Macrophomina genera were the most dominant genera at the examined wheat fields, which could be explained by their high level of adaptation in response to changes in temperature, seasonal moisture distribution, amount of moisture and edaphic factors (Moya-Elizondo et al. 2011).

The high percentage of frequency of the $R$. solani fungus is due to its ability to form sclerotia which are very resistant to the unfavorable conditions in the soil, as well as to their saprophytic activities on plant debris between seasons (Abbas et al. 2017). R. solani fungi cause damping-off with brown or black spots on the roots $1 \mathrm{~mm}$ in size and delay the growth of the wheat plant compared to the control treatment (Gyula et al. 2013). Nirupama et al. (2017) mentioned that $R$. solani causes a number of common diseases such as the damping-off pre- and post-emergence, root rot, stem bases and seed and fruit rot. AL-Musawi et al. (2017) reported that $R$. solani and Fusarium sp. caused diseases of seed rot and dampingoff. Ishtiaq et al. (2019) indicated that $R$. solani fungus is a soil-borne fungus and causes a reduction in yield and causes a soft and dry weight reduction for the roots of wheat. The effect of pathogens on the seedlings may be due to its ability to produce a group of enzymes that cause the fall of these seedlings. For example, $R$. solani produces polygalactoronase (PG), polymethyl-galactoronase (PMG), B-glucosidase and cellulas (Xue et al. 2018), 


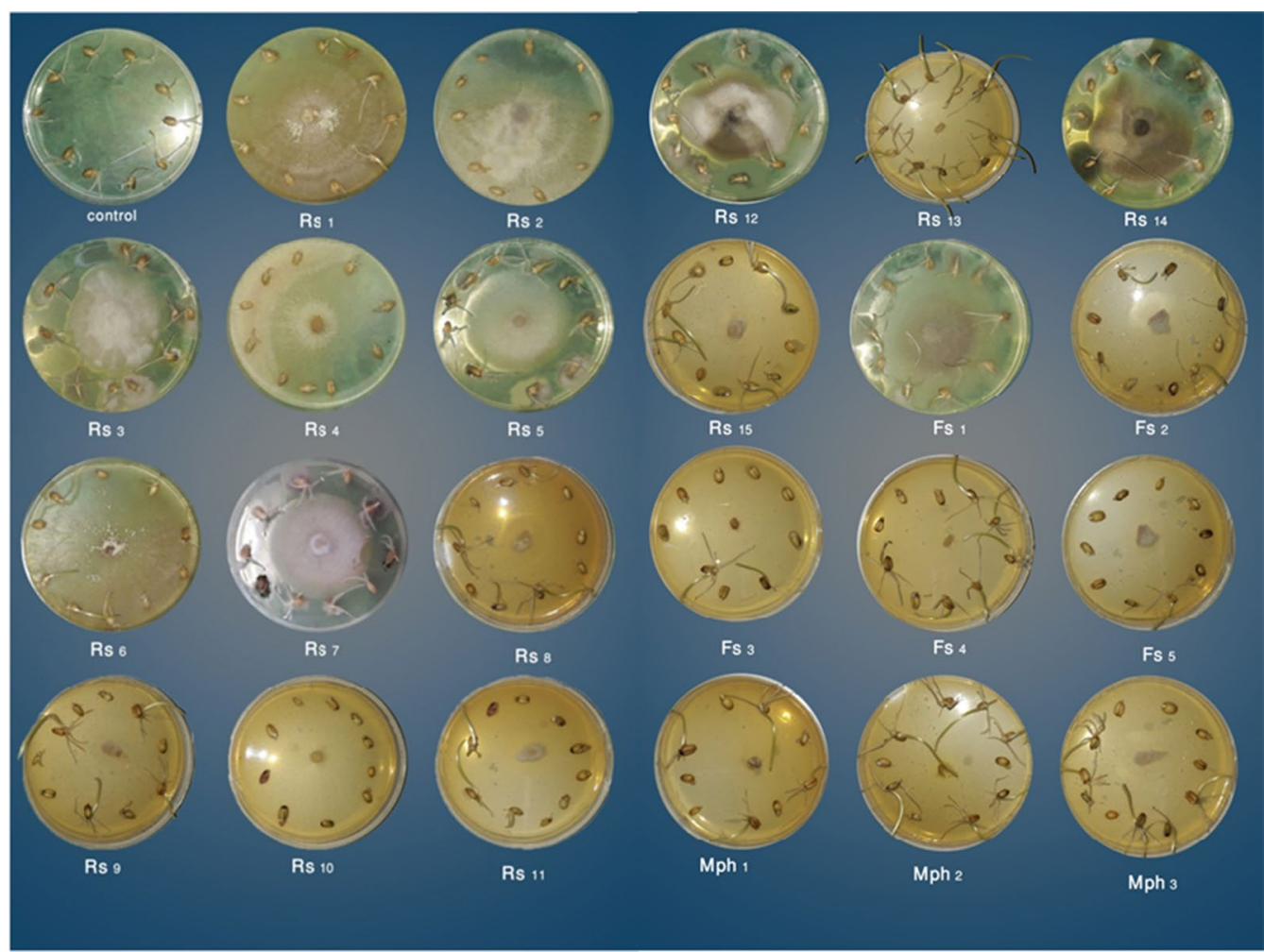

Fig. 10 Effect of R. solani, F. solani and M. phaseolina on germination of wheat seeds on water agar plates

and $F$. solani produces extracellular enzymes such as catalase, cellulose laccase, amylase, protease, lipase and pectinase (Mezzomo et al. 2019). M. phaseolina produces a number of aqueous hydrolysis enzymes that analyze the components of plant cell wall such as cellulose, hemicellulose, pectin and lignin (Islam et al. 2012).

\section{Conclusions}

The present work has been conducted to evaluate the wheat damping-off disease in different fields at Basra and Maysan province, as well as determine the prevalence of disease fungal pathogens at these fields. Basra wheat fields were found to be high in their disease severity, more specifically Al-Qurna wheat fields, compared to Maysan wheat fields. R. solani, Fsolani and M. phaseolina had the highest prevalent rates at all examined fields.

Results of laboratory experiments revealed the pathogenicity of isolated fungi from wheat roots and soils on wheat seeds and seedlings. Future studies are required to evaluate different management practices to control these potential pathogens. 
Table 6 The length of the radicle and the hypocotyl $(\mathrm{cm})$ and the fresh and dry weight $(\mathrm{mg})$ of the radicle and the hypocotyl of wheat in the pot

\begin{tabular}{|c|c|c|c|c|c|c|c|}
\hline No & Isolate & $\begin{array}{l}\text { Radicle length } \\
\text { (cm) }\end{array}$ & $\begin{array}{l}\text { Hypocotyl } \\
\text { length }(\mathrm{cm})\end{array}$ & $\begin{array}{l}\text { fresh weight } \\
\text { of radicle }(\mathrm{mg})\end{array}$ & $\begin{array}{l}\text { Dry weight } \\
\text { of radicle }(\mathrm{mg})\end{array}$ & $\begin{array}{l}\text { Fresh weight } \\
\text { of hypocotyl (mg) }\end{array}$ & $\begin{array}{l}\text { Dry weight } \\
\text { of hypocotyl } \\
\text { (mg) }\end{array}$ \\
\hline 1 & Control & 8.7633 & 9.1000 & 0.0988 & 0.0604 & 0.0875 & 0.0848 \\
\hline 2 & Rs1 & 3.1133 & 2.1667 & 0.0122 & 0.0110 & 0.0357 & 0.0106 \\
\hline 3 & Rs2 & 5.6133 & 5.3400 & 0.0342 & 0.0185 & 0.0549 & 0.0181 \\
\hline 4 & Rs3 & 4.9300 & 4.5033 & 0.0233 & 0.0142 & 0.0284 & 0.0143 \\
\hline 5 & Rs4 & 5.8767 & 5.6000 & 0.0462 & 0.0342 & 0.0433 & 0.0228 \\
\hline 6 & Rs5 & 5.3400 & 4.8667 & 0.0254 & 0.0163 & 0.0338 & 0.0168 \\
\hline 7 & Rs6 & 5.0867 & 4.8200 & 0.0252 & 0.0157 & 0.0284 & 0.0146 \\
\hline 8 & Rs7 & 6.8300 & 6.8400 & 0.0856 & 0.0495 & 0.0552 & 0.0284 \\
\hline 9 & Rs8 & 5.7067 & 5.2800 & 0.0355 & 0.0223 & 0.0367 & 0.0188 \\
\hline 10 & Rs9 & 3.9033 & 3.1000 & 0.0170 & 0.0114 & 0.0163 & 0.0112 \\
\hline 11 & Rs10 & 5.6133 & 5.2800 & 0.0316 & 0.0173 & 0.0355 & 0.0180 \\
\hline 12 & Rs11 & 5.9633 & 5.6600 & 0.0485 & 0.0358 & 0.0164 & 0.0142 \\
\hline 13 & Rs12 & 6.1967 & 6.3233 & 0.0618 & 0.0424 & 0.0508 & 0.0268 \\
\hline 14 & Rs13 & 5.3767 & 4.8667 & 0.0296 & 0.0172 & 0.0353 & 0.0170 \\
\hline 15 & Rs14 & 5.7833 & 5.9067 & 0.0358 & 0.0308 & 0.0380 & 0.0205 \\
\hline 16 & Rs15 & 5.9900 & 5.9067 & 0.0549 & 0.0393 & 0.0456 & 0.0253 \\
\hline 17 & Fs1 & 4.5767 & 4.1367 & 0.0180 & 0.0116 & 0.0164 & 0.0115 \\
\hline 18 & Fs2 & 7.4567 & 7.3100 & 0.0870 & 0.0688 & 0.0552 & 0.0347 \\
\hline 19 & Fs3 & 7.2533 & 7.2700 & 0.0846 & 0.0496 & 0.0367 & 0.0347 \\
\hline 20 & Fs4 & 6.1967 & 6.1333 & 0.0606 & 0.0424 & 0.0458 & 0.0260 \\
\hline 21 & Fs5 & 6.3867 & 6.8400 & 0.0687 & 0.0429 & 0.0539 & 0.0274 \\
\hline 22 & Mph 1 & 4.7067 & 4.1667 & 0.0215 & 0.0132 & 0.0212 & 0.0117 \\
\hline 23 & Mph 2 & 5.8700 & 5.9121 & 0.0445 & 0.0341 & 0.0412 & 0.0212 \\
\hline \multirow[t]{2}{*}{24} & Mph3 & 6.4767 & 6.8800 & 0.0718 & 0.0437 & 0.0549 & 0.0275 \\
\hline & L.S.D & 0.7781 & 0.1596 & 0.0058 & 0.0274 & 0.0314 & 0.00257 \\
\hline
\end{tabular}

Acknowledgements

The authors are thankful for Dr. Yahya Salih (Department of Plant Protection, Collage of Agriculture, University of Basra) for helping in fungal identification.

\section{Authors' contributions}

Q.H. helped in cooperation in fields surveys, sampling and laboratory experiments; A.M. designed the work and data analysis; M.H.A. helped in cooperation in laboratory experiment and manuscript writing. All authors have read and approved the manuscript.

\section{Funding}

The authors declare that they have no funding support during this study.

\section{Availability of data and materials \\ Not applicable.}

\section{Declarations}

Ethics approval and consent to participate

Not applicable (this study does not involve human participants, human data or human tissue).

\section{Consent for publication}

Not applicable.

\section{Competing interests}

The authors declare that they have no competing interests.
Received: 6 Auqust 2020 Accepted: 22 February 2021

Published online: 04 March 2021

\section{References}

Abbas A, Jiang D, Fu Y (2017) Trichoderma spp as antagonist of Rhizoctonia solani. J Plant Pathol Microbiol 8:402. https://doi.org/10.4172/21577471.1000402

Acuña R. (2008) Compendio de fitopatógenos de cultivos agrícolas en Chile. 123 pp. Servicio Agrícola y Ganadero (SAG), División Protección Agrícola, Santiago, Chile

AL-Musawi MA, Lahov AA, Jaafar OH (2017) Isolation and diagnosis of the pathogens causing seed decay and damping-off disease on wheat and control them using some biological and chemical factors. Karbala J Agric Sci 4(1) (in Arabic language).

Andrade O, Campillo R, Peyrelongue A, Barrientos L (2011) Soils suppressive against Gaeumannomyces graminis var. tritici identified under wheat crop monoculture in southern Chile. Ciencia e Investigación Agraria 38:345-356. https://doi.org/10.4067/S0718-16202011000300004

AOSA (1983) Association of Official Seed Analysts Seed Vigour Testing Handbook. Contribution32 to Handbook on SeedTesting Association of Official Seed Analysts, Lincoln, NE, USA, p 88

Cook RJ (2010) Fusarium root, crown, and foot rots and associated seedling diseases. In: Bockus WW, Bowden R, Hunger R, Morrill W, Murray T, Smiley $R$ (eds) Compendium of wheat diseases and pests, 3rd edn. The Pennsylvania State University Press, University Park, pp 37-39 
Dewan MM (1989) Identity and frequency of occurrence of fungi in root of wheat and rye grass and their effect on take-all and host growth. Ph.D. thesis Univ. Western Australia

Domsch KH, Gams W, Anderson T (2007) Compendium of soil fungi, 2nd edn. IHW-Verlag, Eching, p 672. https://doi.org/10.111 1/j.1365-2389.2008.01052_1.x

Dugan FM (2006) The identification of fungi an illustrated introduction with keys, glossary, and guide to literature. U.S. Department of Agriculture, Agricultural Research Service, Washington State University Pullman, p 176

Ernesto M, Nolberto A, María PC, Herman D (2015) Distribution and prevalence of crown rot pathogens affecting wheat crops in southern Chile. Chilean J Agric Res. https://doi.org/10.4067/S0718-58392015000100011

FAO (2018) Food and Agriculture Organization of the United Nations Database Results, Geneva. 2018. http://www.fao.org/faostat/en/\#data/QC

Farazimah Y, Hussein T, Pooja Sh (2019) Isolation of fungi from various habitats and their possible bioremediation. Curr Sci 116(5):733-740

Gyula O, Zoltán N (2013) Donát M (2013) Susceptibility of wheat varieties to soil-borne Rhizoctonia infection. Am J Plant Sci 4:2240-2258

Ishtiaq M, Tanveer H, Khizarhayat B, Tony A, Mehwish M, Shehzad A, Abul Ghani A (2019) Management of root rot diseases of eight wheat varieties using resistance and biological control agents techniques. Pak J Bot. https://doi. org/10.30848/PJB2019-1(16)

Islam Md, Shahidul Md, Samiul H, Mohammad MI, Emdadul ME, Abdul Halim QM, Mosaddeque H, Zakir H, Borhan A, Sifatur R, Sharifur R, Monjurul A, Shaobin H, Xuehua W, Jennifer AS (2012) Maqsudul A (2012) Tools to kill: genome of one of the most destructive plant pathogenic fungi Macrophomina phaseolina. BMC Genomics 13:493

ISTA (2005) International Seed Testing Association International Rules for Seed Testing. Adopted at the Ordinary Meeting.2004, Budapest, Hungary to become effective

Jones RW, Pettit RE, Taber RA (1984) Lignite and stillage: carrier and substrate for application of fungal biocontrol agent to soil. Am Phytopathol Soc 74:1167-1170. https://doi.org/10.1094/Phyto-74-1167

Kaur N (2016) Root rot pathogens of wheat in South Dakota and their effect on seed germination and seedling blight in spring wheat cultivars. Theses and Dissertations 1117. https://doi.org/10.5586/aa.1657

Leslie JF, Summerell BA (2006) The fusarium laboratory manual. Blackwell Publishing, Ames

Marconi E, Carcea M (2001) Pasta from nontraditional raw materials. Cereal Foods World 46:522-529

Mesterhazy A, Bartok T, Kaszonyi G, Varga M, Toth B, Varga J (2005) Common resistance to different Fusarium spp. causing Fusarium head blight in wheat. Euro J Plant Path. https://doi.org/10.1590/1678-992x-2016-0407

Mezzomo R, Rolim JM, Santos AF, Poletto T, Walker C, Maciel CG, Muniz MFB (2019) Aggressiveness of Fusarium oxysporum and F. solani isolates to yerba-mate and production of extracellular enzymes. Summa Phytopathologica 45(2):141-145

Minati MH, Mohammed-Ameen MK (2019) Interaction between Fusarium head blight and crown rot disease incidence and cultural practices on wheat in the south of Iraq, Basra province. Bull Natl Res Cent 43:200. https ://doi.org/10.1186/s42269-019-0257-9

Moya-Elizondo E, Rew RL, Jacobsen B, Hogg AC, Dyer AT (2011) Distribution and prevalence of Fusarium crown rot and common root rot pathogens of wheat in Montana. Plant. https://doi.org/10.1094/PDIS-11-10-0795

Nicol JM, Bagci A, Hekimhan H, Bolat N, Braun HJ, Trethowan R (2004) Strategy for the identification and breeding of resistance to dryland root rot complex for international spring and winter wheat breeding programs. In: Proceedings of 4th International Crop Science Congress, Brisbane, Australia, p 283

Nirupama RK, Devi BS, Devi S (2017) Native Trichoderma for the management of wire stem of mustard (Brassica spp.) caused by Rhizoctonia solani. Int J Curr Microbiol Appl Sci. https://doi.org/10.20546/ijcmas.2017.609.284

Nyongesa BW, Okoth S, Ayugi V (2015) Identification key for Aspergillus species isolated from maize and soil of Nandi County, Kenya. Adv Microbiol 5:205-229. https://doi.org/10.4236/aim.2015.54020

Pathak V, Shrivastav S (2015) Biochemical studies on wheat (Triticum aestivum L.). J Pharmacognosy Phytochem 4(3):171

Paulitz TC, Smiley RW, Cook RJ (2002) Insight into the prevalence and management of soilborne cereal pathogens under direct seeding in the Pacific Northwest, USA. Can J Plant Path 24:416-428

Pooja S, Prashant S, Singh MP (2015) Assessment of antifungal activity of PGPR (plant growth promoting rhizobacterial) isolates against Rhizoctonia solani in wheat. Int J Adv Res 3(10):803-812

Tunali B, Nicol JM, Hodson D, Uçkun Z, Büyük O, Erdurmuş D, Hekimhan H, Aktaş H, Akbudak MA, Bağcı SA (2008) Root and crown rot fungi associated with spring, facultative, and winter wheat in Turkey. Plant Dis 92:1299-1306

Watanabe T (2002) Pictorial atlas of soil and seed fungi: morphologies of cultured fungi and the key to species, 2nd edn. CRC Press, Boca Raton. https ://doi.org/10.1201/9781420040821

Xue CY, Zhou RJ, Li YJ, Xiao D, Fu JF (2018) Cell-wall-degrading enzymes produced in vitro and in vivo by Rhizoctonia solani, the causative fungus of peanut sheath blight. PeerJ 6:e5580. https://doi.org/10.7717/peerj.5580

Yonghao L (2013) Department of plant pathology and ecology. The Connecticut Agricultural Experiment station. https://www.ct.gov/caes.

\section{Publisher's Note}

Springer Nature remains neutral with regard to jurisdictional claims in published maps and institutional affiliations.

\section{Submit your manuscript to a SpringerOpen ${ }^{\odot}$ journal and benefit from:}

- Convenient online submission

- Rigorous peer review

- Open access: articles freely available online

- High visibility within the field

- Retaining the copyright to your article

Submit your next manuscript at springeropen.com 